\title{
Ripening Behaviour of Chitosan Coated Sapota Fruits under Low Temperature Storage Condition
}

\author{
Prahlad Deb $^{1^{*}}$ and S. Gautam ${ }^{2}$ \\ ${ }^{1}$ Department of Horticulture \& Postharvest Technology, Institute of Agriculture, \\ Visva-Bharati, Sriniketan-731236, West Bengal, India \\ ${ }^{2}$ Food Science \& Safety Section, Food Technology Division, Bhabha Atomic Research Centre, \\ Trombay, Mumbai, India \\ *Corresponding author
}

\begin{tabular}{|l|}
\hline Ke y w o r d s \\
$\begin{array}{l}\text { Sapota, Chitosan } \\
\text { coating, Storage, } \\
\text { Quality }\end{array}$ \\
\hline Article Info \\
\hline $\begin{array}{l}\text { Accepted: } \\
\text { 20 September } 2018 \\
\text { Available Online: } \\
\text { 10 October } 2018\end{array}$ \\
\hline
\end{tabular}

A B S T R A C T

Sapota (Achras zapota L.) is one of the tropical climacteric fruits preferred by the consumers due to its sweet taste and aroma. Fruits become ripe very quickly after harvesting due to sudden climacteric rise with high respiration rate and ethylene production. This quick ripening causes loosening the texture of fruit leads to softening of and spoilage. The short shelf life of the fruit is a marketing problem which is a major cause of huge postharvest loss of this fruit. Edible coating of fruits can reduce the ripening rate by making a thin layer above fruit surface to interfere gaseous exchange between air and fruit which ultimately reduce respiration rate and ripening. Chitosan is one such edible coating material frequently used in fruits to enhance storage life. In the present experiment solution of chitosan powder $(0.5,1.0,1.5$ and $2.0 \% \mathrm{w} / \mathrm{v})$ has been prepared in $0.5 \%$ glacial acetic acid with surfactant and plasticizer. Freshly harvested and washed sapota fruits were then dipped in coating solution for $1 \mathrm{~min}$ followed by air drying. Fruits were then stored in controlled condition $\left(12+1{ }^{\circ} \mathrm{C}, 85-90 \% \mathrm{RH}\right)$. $1.5 \%$ chitosan coating resulted best for keeping the maximum fruits (more than $75 \%$ ) for 30 days under controlled condition. Chitosan coating also reduced the physiological losses in weight compared to the uncoated fruits. The same treatment has also resulted maximum retention of quality by maximum TSS, total sugar and reducing sugar.

\section{Introduction}

Sapota (Achras zapota L.) is one of the tropical climacteric fruits preferred by the consumers due to its sweet taste and aroma. Fruits are mainly used as table purpose as fresh, fruit salad, milk shake or processed like squash, jam, candy etc. The fruit is very nutritious and rich in carbohydrate, calcium, phosphorus and antioxidants like beta carotene and ascorbic acid etc. In India major sapota growing states are Karnataka, Maharashtra, Gujarat, Tamil Nadu, Andhra Pradesh and West Bengal (Anon. 2017). Fruits become ripe very quickly after harvesting due to sudden climacteric rise with high respiration rate and ethylene production. The quick ripening of fruits cause loosening the texture of fruit leads to softening of and spoilage which is main cause of perishable nature of the fruit (Jagtap 
and Katrodia, 1998). Sapota is one of the climacteric fruit and thus the rise in respiration rate and ethylene production is very quick and high after harvest (Sankaranarayan et al., 2007). High respiration results the loss of stored carbohydrate causing deterioration of fruit quality. Besides higher transpiration rate causes maximum physiological losses in weight and the fruits loss its turgidity. The short shelf life of the fruit is a marketing problem which is a major cause of huge postharvest loss of this fruit. Inspite of the considerable production of this fruit tremendous post-harvest loss (Gajanana et al., 2006) is one bottleneck to the growers.

Chitosan is a linear polysacchiride of $(1,4)$ linked 2-amio-deoxy- $\beta$-D-glucan. It is a deacetylated derivative of chitin which is a naturally available polysaccharide (Youwei and Yinzhe, 2013). It has found to be nontoxic, biodegradable, biocompatible polysaccharide having antimicrobial and antifungal activity (Majeti and Ravi, 2000). This edible coating can form a semi permeable film above fruit surface and can reduce respiration rate by adjusting the permeability of oxygen and carbon di-oxide. It can also act as barrier to propagate harmful microbes above fruit surface thus coated fruits can be stored for longer period. Additionally chitosan coating can also reduce the transpiration loss. Considering these attributes chitosan is used as edible coating in many fruits (Mohammed, 2010). Thus the present experiment was undertaken to study the effect of chitosan coating on sapota fruits on its ripening behaviour under low temperature storage.

\section{Materials and Methods}

Present research work has been carried out at the laboratory of Department of Horticulture \& Postharvest Technology, Institute of Agriculture, Visva-Bharati University, Sriniketan, West Bengal during the year 2015-
16. Following are the steps followed for the present experiment.

Preparation of chitosan solution and treatment of fruits

Chitosan powder of different concentrations i.e. $0.5,1.0,1.5$ and $2.0 \% \mathrm{w} / \mathrm{v}$ were dissolved in $100 \mathrm{ml}$ of $0.5 \%$ glacial acetic acid solution. $0.1 \mathrm{ml}$ each of tween-80 (as surfactant) and glycerol (as plasticizer) were added to the solution. The freshly harvested fruits were washed in water dried and dipped in coating solution for $1 \mathrm{~min}$ followed by air drying. Fruits were then stored in controlled condition $\left(12+1{ }^{\circ} \mathrm{C}, 85-90 \% \mathrm{RH}\right)$.

\section{Observations recorded}

Different observations have been taken on each fifth day upto $35^{\text {th }}$ day. The following are the observations have considered in the present experiment in the present study:

\section{Physiological losses in weight (PLW)}

The physiological losses in weight of fruit mainly occur due to transpiration and respiration. It was calculated with the following formula:

Initial weight of fruits - Final weight of fruits PLW $(\%)=$------------------------------ X 100 Initial weight of fruits

\section{Fruit pressure}

Fruit pressure actually denotes the turgidity of the fruits and measured by fruit pressure tester, expressed in $\mathrm{Kg}$.

\section{Shelf life}

Number of healthy fruits out of 100 fruits was considered as the indicator shelf life for particular day. Maximum number in latest day 
of storage was considered maximum in storage life.

\section{Total Soluble Solid (TSS)}

Total soluble solid of ber were estimated with the help of a hand refractometer. A drop of fruit juice was squeezed out and strained clear juice was instilled on the plate to record the refractometer reading, calibrated in ${ }^{\circ}$ Brix at room temperature.

\section{Total sugar}

Total sugar content of the fruit was determined by titrimetic procedures. Firstly non reducing sugar contain of pulp sample was converted into reducing sugar by acid hydrolysis. After conversion, the sugar of the aqueous solution was determined by titrating against the freshly made mixture containing equal volume of Fehling's solution.

\section{Reducing sugar}

The reducing sugar content of the aqueous extract was determined by titrating against the Fehling's solutions as stated above.

Statistical analysis was done as per Gomez and Gomez (1984) following the standard procedure in Completely Randomized Design with seven treatments and three replication.

\section{Results and Discussion}

Observations on physiological losses in weight, fruit pressure, total soluble solids, total sugar and reducing sugar have been taken five days interval upto $35^{\text {th }}$ day of storage and the significant findings are as follows:

\section{Physiological losses in weight (PLW)}

In the present experiment chitosan coating significantly reduced the physiological losses in weight (Table 1). Maximum PLW was recorded in control or non-coated fruits and it was $17.23 \%$ on $35^{\text {th }}$ day. Minimum PLW was observed under chitosan@2.0\% measured as $8.93 \%$ and $11.25 \%$ on $30^{\text {th }}$ day and $35^{\text {th }}$ day respectively. Chitosan @ $1.5 \%$ resulted $10.34 \%$ of PLW on $30^{\text {th }}$ days of storage and $13.07 \%$ on $35^{\text {th }}$ day. This may be due to the formation of a thin layer above the fruit surface which prevented transpiration loss to a certain limit (Macwan et al., 2018). This may also be due to the formation of modified atmosphere above the fruit surface which inhibited the moisture loss and thereby physiological losses in weight (Park, 1999).

\section{Fruit pressure}

In the present experiment chitosan coating of fruits also resulted better fruit pressure retention significantly (Table 2). Fruit pressure retention was maximum upto $30^{\text {th }}$ day $(1.98$ $\mathrm{kg}$ ) in the fruits treated with chitosan @ 1.5\%. Fruit pressure has been then reduced to 1.46 $\mathrm{kg}$ on $35^{\text {th }}$ day under chitosan @ 1.5\%.2.0\% chitosan coating of fruits also resulted higher fruit pressure retention $(1.72 \mathrm{~kg})$ on $30^{\text {th }}$ days of storage. Textural loss of fruits were observed in the fruits under no coating of chitosan and it was observed significantly minimum $\left(1.50 \mathrm{~kg}\right.$ on $30^{\text {th }}$ day and $0.91 \mathrm{~kg}$ on $35^{\text {th }}$ days of storage). The retention of fruit pressure in the coated fruits is due to slower ripening rate facilitated by the formation of modified atmosphere by chitosan coating (Vishwasrao and Ananthanarayan, 2016).

\section{Shelf life}

Chitosan coating enhanced the shelf life of sapota fruits significantly in the present experiment (Table 3). All the treated and nontreated fruits exhibited a good shelf life (more than 80 percent fresh fruits) upto $30^{\text {th }}$ days of storage under controlled condition. However, the fruits coated with chitosan @ 1.5\% 
exhibited significantly maximum shelf life (86 fresh fruits) on $30^{\text {th }}$ days of storage. A sudden decrease in shelf life from 81 to 68 percent of fresh fruits from $30^{\text {th }}$ day to $35^{\text {th }}$ day under non-treated fruits was also noticed in the present experiment. Dey et al., (2014) reported better shelf life of fruits when edible coating is applied. Menezes and Athmaselvi (2016) also reported that the edible coating can increase the shelf life of fruits. Thus the findings of the present experiment is scientifically justified by the findings of Dey et al., (2014) and Menezes and Athmaselvi (2016).

\section{Total Soluble Solid (TSS)}

In every treatment a rise in the content of total soluble solids was observed in the present experiment (Table 4). The maximum rise of TSS (23.1 ${ }^{\circ}$ Brix) was observed in the fruits treated with chitosan @ $1.5 \%$ on $30^{\text {th }}$ days of storage.

On contrary non-coated and other chitosan coated fruits@0.5,1.0 and 2.0\% showed maximum rise of TSS on $25^{\text {th }}$ days of storage measuring 21.9, 22.5, 21.8 and $21.3{ }^{\circ}$ Brix respectively. It indicates the slow ripening in case of chitosan coating @ 1.5\% and faster ripening in other cases. Similar finding was observed by Tharanathan (2003), Dey et al., (2014) and Menezes and Athmaselvi (2016).

Perhaps higher TSS in chitosan coated fruits was due to the slower respiration rate enhanced by modified atmosphere formed with chitosan layer (Park, 1999).

Table.1 Changes in Physiological losses in weight (PLW \%)

\begin{tabular}{|c|c|c|c|c|c|c|c|c|}
\hline Treatments & $\begin{array}{l}\text { 1st } \\
\text { day }\end{array}$ & $\begin{array}{l}\text { 5th } \\
\text { day }\end{array}$ & $\begin{array}{l}\text { 10th } \\
\text { day }\end{array}$ & $\begin{array}{l}\text { 15th } \\
\text { day }\end{array}$ & $\begin{array}{l}\text { 20th } \\
\text { day }\end{array}$ & $\begin{array}{l}\text { 25th } \\
\text { day }\end{array}$ & $\begin{array}{l}\text { 30th } \\
\text { day }\end{array}$ & $\begin{array}{l}\text { 35th } \\
\text { day }\end{array}$ \\
\hline T1 (Chitosan@ 0.0\%) & 0.0 & 1.25 & 3.93 & 6.55 & 8.17 & 10.42 & 14.78 & 17.23 \\
\hline T2 (Chitosan@ 0.5\%) & 0.0 & 1.20 & 2.08 & 4.26 & 6.46 & 9.55 & 12.31 & 15.94 \\
\hline T3 (Chitosan@ 1.0\%) & 0.0 & 1.01 & 1.97 & 4.67 & 5.93 & 8.80 & 11.15 & 13.53 \\
\hline T4 (Chitosan @ 1.5\%) & 0.0 & 0.95 & 1.53 & 3.96 & 5.64 & 8.88 & 10.34 & 13.07 \\
\hline T5 (Chitosan @ 2.0\%) & 0.0 & 0.78 & 1.15 & 3.48 & 5.31 & 6.88 & 8.93 & 11.25 \\
\hline $\mathrm{SE} \pm \mathrm{M}$ & -- & NS & 0.12 & 0.10 & 0.13 & 0.17 & 0.19 & 0.28 \\
\hline CD (0.05) & - & NS & 0.36 & 0.31 & 0.40 & 0.52 & 0.57 & 0.84 \\
\hline
\end{tabular}

Table.2 Changes in fruit pressure $(\mathrm{Kg})$

\begin{tabular}{|l|l|l|l|l|l|l|l|l|}
\hline Treatments & $\begin{array}{c}\text { 1st } \\
\text { day }\end{array}$ & $\begin{array}{c}\text { 5th } \\
\text { day }\end{array}$ & $\begin{array}{c}\text { 10th } \\
\text { day }\end{array}$ & $\begin{array}{c}\text { 15th } \\
\text { day }\end{array}$ & $\begin{array}{c}\text { 20th } \\
\text { day }\end{array}$ & $\begin{array}{c}\text { 25th } \\
\text { day }\end{array}$ & $\begin{array}{c}\text { 30th } \\
\text { day }\end{array}$ & $\begin{array}{c}\text { 35th } \\
\text { day }\end{array}$ \\
\hline T1 (Chitosan@ 0.0\%) & 3.56 & 3.24 & 3.03 & 2.86 & 2.51 & 2.20 & 1.50 & $\mathbf{0 . 9 1}$ \\
\hline T2 (Chitosan@ 0.5\%) & 3.49 & 3.11 & 2.95 & 2.72 & 2.45 & 2.08 & 1.57 & $\mathbf{0 . 9 9}$ \\
\hline T3 (Chitosan@ 1.0\%) & 3.50 & 3.20 & 3.05 & 2.79 & 2.46 & 2.10 & 1.63 & $\mathbf{0 . 9 3}$ \\
\hline T4(Chitosan@ 1.5\%) & 3.51 & 3.36 & 3.11 & 2.93 & 2.67 & 2.36 & 1.98 & $\mathbf{1 . 4 6}$ \\
\hline T5 (Chitosan @ 2.0\%) & 3.46 & 3.07 & 2.97 & 2.69 & 2.32 & 2.05 & 1.72 & 1.10 \\
\hline SE+M & NS & NS & NS & NS & NS & NS & 0.07 & $\mathbf{0 . 0 6}$ \\
\hline CD $(\mathbf{0 . 0 5})$ & NS & NS & NS & NS & NS & NS & $\mathbf{0 . 2 3}$ & $\mathbf{0 . 2 0}$ \\
\hline
\end{tabular}


Table.3 Shelf life of fruits (no. of healthy fruits)

\begin{tabular}{|c|c|c|c|c|c|c|c|c|}
\hline Treatments & $\begin{array}{l}\text { 1st } \\
\text { day }\end{array}$ & $\begin{array}{l}\text { 5th } \\
\text { day }\end{array}$ & $\begin{array}{l}\text { 10th } \\
\text { day }\end{array}$ & $\begin{array}{l}\text { 15th } \\
\text { day }\end{array}$ & $\begin{array}{l}\text { 20th } \\
\text { day }\end{array}$ & $\begin{array}{l}\text { 25th } \\
\text { day }\end{array}$ & $\begin{array}{l}\text { 30th } \\
\text { day }\end{array}$ & $\begin{array}{l}\text { 35th } \\
\text { day }\end{array}$ \\
\hline T1 (Chitosan @ 0.0\%) & 100 & 100 & 100 & 100 & 94 & 87 & 81 & 68 \\
\hline T2 (Chitosan @ 0.5\%) & 100 & 100 & 100 & 100 & 96 & 91 & 80 & 72 \\
\hline T3 (Chitosan @ 1.0\%) & 100 & 100 & 100 & 100 & 95 & 89 & 80 & 74 \\
\hline T4 (Chitosan @ 1.5\%) & 100 & 100 & 100 & 100 & 99 & 93 & 86 & 78 \\
\hline T5 (Chitosan @ 2.0\%) & 100 & 100 & 100 & 95 & 91 & 84 & 79 & 70 \\
\hline $\mathrm{SE}+\mathrm{M}$ & NS & NS & NS & NS & 0.68 & 1.24 & 1.37 & 1.26 \\
\hline CD (0.05) & NS & NS & NS & NS & 2.05 & 3.72 & 4.11 & 3.78 \\
\hline
\end{tabular}

Table.4 Changes in total soluble solids (TSS ${ }^{\circ}$ Brix)

\begin{tabular}{|l|c|c|c|c|c|c|c|c|}
\hline Treatments & $\begin{array}{c}\text { 1st } \\
\text { day }\end{array}$ & $\begin{array}{c}\text { 5th } \\
\text { day }\end{array}$ & $\begin{array}{c}\text { 10th } \\
\text { day }\end{array}$ & $\begin{array}{c}\text { 15th } \\
\text { day }\end{array}$ & $\begin{array}{c}\text { 20th } \\
\text { day }\end{array}$ & $\begin{array}{c}\text { 25th } \\
\text { day }\end{array}$ & $\begin{array}{c}\text { 30th } \\
\text { day }\end{array}$ & $\begin{array}{c}\text { 35th } \\
\text { day }\end{array}$ \\
\hline T1 (Chitosan @ 0.0\%) & 7.2 & 11.8 & 15.7 & 17.5 & 19.4 & 21.9 & 20.3 & $\mathbf{1 8 . 6}$ \\
\hline T2 (Chitosan @ 0.5\%) & 7.5 & 11.0 & 14.5 & 18.1 & 20.7 & 22.5 & 21.1 & $\mathbf{1 9 . 3}$ \\
\hline T3 (Chitosan @ 1.0\%) & 7.6 & 11.4 & 14.2 & 17.2 & 18.9 & 21.8 & 20.4 & $\mathbf{1 8 . 7}$ \\
\hline T4 (Chitosan @ 1.5\%) & 7.1 & 10.5 & 13.7 & 16.5 & 19.2 & 22.7 & 23.1 & $\mathbf{2 1 . 6}$ \\
\hline T5(Chitosan @ 2.0\%) & 7.4 & 10.8 & 13.6 & 16.9 & 19.7 & 21.3 & 19.5 & $\mathbf{1 8 . 0}$ \\
\hline SE+M & NS & NS & 0.40 & 0.42 & 0.35 & 0.35 & 0.48 & $\mathbf{0 . 4 4}$ \\
\hline CD (0.05) & NS & NS & 1.11 & $\mathbf{1 . 2 0}$ & $\mathbf{1 . 0 2}$ & $\mathbf{1 . 0 6}$ & $\mathbf{1 . 4 1}$ & $\mathbf{1 . 3 2}$ \\
\hline
\end{tabular}

Table.5 Changes in total sugar (\%)

\begin{tabular}{|l|l|l|l|l|l|l|l|l|}
\hline Treatments & $\begin{array}{c}\text { 1st } \\
\text { day }\end{array}$ & $\begin{array}{c}\text { 5th } \\
\text { day }\end{array}$ & $\begin{array}{c}\text { 10th } \\
\text { day }\end{array}$ & $\begin{array}{c}\text { 15th } \\
\text { day }\end{array}$ & $\begin{array}{c}\text { 20th } \\
\text { day }\end{array}$ & $\begin{array}{c}\text { 25th } \\
\text { day }\end{array}$ & $\begin{array}{c}\text { 30th } \\
\text { day }\end{array}$ & $\begin{array}{c}\text { 35th } \\
\text { day }\end{array}$ \\
\hline T1 (Chitosan @ 0.0\%) & 8.3 & 9.3 & 11.8 & 13.9 & 16.8 & 15.6 & 15.2 & $\mathbf{1 3 . 5}$ \\
\hline T2 (Chitosan @ 0.5\%) & 8.0 & 8.7 & 10.1 & 10.9 & 12.3 & 14.8 & 16.0 & $\mathbf{1 5 . 1}$ \\
\hline T3 (Chitosan @ 1.0\%) & 8.1 & 9.5 & 10.4 & 11.7 & 15.5 & 16.1 & 15.7 & $\mathbf{1 5 . 2}$ \\
\hline T4 (Chitosan @ 1.5\%) & 8.2 & 8.9 & 9.7 & 10.6 & 11.9 & 14.5 & 18.2 & $\mathbf{1 7 . 4}$ \\
\hline T5 (Chitosan @ 2.0\%) & 8.3 & 10.5 & 12.7 & 16.9 & 16.1 & 15.2 & 14.3 & $\mathbf{1 3 . 0}$ \\
\hline SE+M & NS & NS & 0.36 & 0.42 & 0.44 & 0.40 & 0.46 & $\mathbf{0 . 3 9}$ \\
\hline CD (0.05) & NS & NS & $\mathbf{1 . 1 2}$ & $\mathbf{1 . 2 5}$ & $\mathbf{1 . 3 1}$ & $\mathbf{1 . 2 2}$ & $\mathbf{1 . 0 5}$ & $\mathbf{1 . 1 6}$ \\
\hline
\end{tabular}

Table.6 Changes in reducing sugar (\%)

\begin{tabular}{|c|c|c|c|c|c|c|c|c|}
\hline Treatments & $\begin{array}{l}\text { 1st } \\
\text { day }\end{array}$ & $\begin{array}{l}\text { 5th } \\
\text { day }\end{array}$ & $\begin{array}{l}\text { 10th } \\
\text { day }\end{array}$ & $\begin{array}{l}\text { 15th } \\
\text { day }\end{array}$ & $\begin{array}{l}\text { 20th } \\
\text { day }\end{array}$ & $\begin{array}{l}\text { 25th } \\
\text { day }\end{array}$ & $\begin{array}{l}\text { 30th } \\
\text { day }\end{array}$ & $\begin{array}{l}\text { 35th } \\
\text { day }\end{array}$ \\
\hline T1 (Chitosan @ 0.0\%) & 1.5 & 2.6 & 3.3 & 5.8 & 8.3 & 7.6 & 7.0 & 6.2 \\
\hline T2 (Chitosan @ 0.5\%) & 1.6 & 2.1 & 3.2 & 4.5 & 7.3 & 7.9 & 8.7 & 6.8 \\
\hline T3 (Chitosan @ 1.0\%) & 1.3 & 1.8 & 2.6 & 3.9 & 6.7 & 8.1 & 7.5 & 7.0 \\
\hline T4(Chitosan @ 1.5\%) & 1.7 & 2.5 & 3.6 & 5.5 & 7.1 & 8.4 & 9.7 & 8.5 \\
\hline T5 (Chitosan @ 2.0\%) & 1.4 & 2.5 & 4.4 & 7.8 & 8.4 & 7.2 & 6.5 & 6.1 \\
\hline $\mathrm{SE}+\mathrm{M}$ & NS & NS & NS & 0.41 & 0.33 & 0.30 & 0.29 & 0.30 \\
\hline CD (0.05) & NS & NS & NS & 1.27 & 1.01 & 0.90 & 0.85 & 0.88 \\
\hline
\end{tabular}




\section{Total sugar}

As the ripening progressed with the storage of fruits under controlled condition in the present experiment the content of total sugar also increased upto the peak of ripening of sapota fruits (Table 5). The changes of total sugar content of sapota fruits as effected by chitosan coating was more or less similar with the changes in TSS of the fruits. Maximum content of total sugar (18.3\%) was recorded in the fruits coated with chitosan @ 1.5\% on the $30^{\text {th }}$ days of storage. However in all other treatments the peak of total sugar content of fruits were fund on $25^{\text {th }}$ days of storage which denotes the slower ripening in chitosan coating @ 1.5\% and faster ripening in others. The total sugar content of fruits coated with chitosan@1.5\% on $35^{\text {th }}$ days of storage maintained a standard of $17.4 \%$. The finding of the present experiment is supported by the findings of Tharanathan (2003) and those of Vishwasrao and Ananthanarayan (2016).

\section{Reducing sugar}

The perusal of the data presented in the table number, it is clear that the chitosan coating enhanced the shelf life of fruits by slowering the ripening process which has been exhibited by slow rise in reducing sugar content of sapota fruits in the present experiment (Table 6). Chitosan coating of $1.5 \%$ has shown maximum rise of reducing sugar $(9.7 \%)$ of fruits on $30^{\text {th }}$ days of storage after which it has been reduced to a standard of $8.5 \%$ on $35^{\text {th }}$ days of storage indicating the longer consumability of the fruits under same treatment. Non-coated fruits exhibited faster rise in peak of reducing sugar measuring $8.3 \%$ on $20^{\text {th }}$ day of storage which further reduced to $6.2 \%$ on $35^{\text {th }}$ days of storage of sapota fruits under controlled condition.

$1.5 \%$ chitosan coating resulted best for keeping the maximum fruits (more than $75 \%$ ) for 30 days under controlled condition. Minimum physiological losses in weight, maximum retention of quality with respect to highest TSS, total sugar and reducing sugar in the fruits coated with chitosan @ 1.5\% indicated the best treatment in the present experiment.

\section{Acknowledgement}

Authors are thankful to Board of Research in Nuclear Sciences, Department of Atomic Energy, Govt. of India for financial assistance through research project under which the present experiment has been conducted.

\section{References}

A.O.A.C (1984) Official Method of Analysis VOL-II, Association of Official Analytical Chemists, Ed. Kenneth Helrich, Virginia, USA, Pp: 910-928

Anonymous, 2017. Horticultural Statistics at a Glance, Horticultural Statistics Division, Department of Agriculture, Co-operation and Farmers Welfare, Ministry of Agriculture \& Farmers Welfare, Govt. of India

Damodaran, T., Attri, B.L., Medhi, R.P., Nair, S.A. and Alex, L. (2001) Studies on post-harvest of sapota (Achras zapota L.)cv. Cricket Ball during storage, Indian J. Hort., 58: 342-345.

Dey, K., Ghosh, A., Bhowmick, N. and Ghosh, A. 2014. Physico-chemical properties of sapota (Manilkara achras (Mill) Fosberg.) fruits coated with corn starch. J. Crop Weed, 10:43-49

Gajanana, T. M., Sudha, M. and Dakshinamoorthy, V. (2006) Marketing and postharvest loss assessment in sapota, J. Hort. Sci. 1(1):71-75

Gautam, S. K., Chundawat, B. S. (1989) Postharvest changes in sapota cv. 'Kalipatti': I-Effect of various post- 
harvest treatments on biochemical changes. Indian J. Hort., 46: 310-315.

Gomez, K. A. and Gomez, A. A. (1984) Statistical Procedures for Research Workers, John Willey \& Sons, USA, Pp: 8-20

Jagtap, K.B. and Katrodia, J.S. (1998) Postharvest losses in packaging and transportation of sapota, Indian J.Hort., 55:48-51.

Majeti NV, Ravi K (2000) A review of chitin and chitosan applications. React Funct Polym., 46: 1-27

Menezes, J., Athmaselvi, K. M. 2016. Polysaccharide based edible coating on sapota fruit. The J. of Institute of Agrophysics of Polish Acad. of Sci., 30(4):551-557.

Mohammed A (2010) Chitosan application for active bio-based films production and potential in the food industry: Review. Food Sci Technol-LEB., 43: 837-842.

Park, H. J. 1999. Development of advanced edible coatings for fruits. Trends in Food Sci. \& Tech., 10:254-260.
Sankaranarayanan, R., Geetharani, P., Manivannan, M. I. (2007) Ripening behaviour of sapota, South Indian Hort., 55: 276-282.

Sudha, R., Amutha, R., Muthulaksmi, S., Rani, W. and Indira, K. (2007) Influence of Pre and Postharvest Chemical Treatments on Physical characteristics of sapota (Achras zapota L.) var. PKM 1. Res. J. of Agri. and Bio Sci., 3: 450-452.

Tharanathan, R.N. 2003. Biodegradable films and composite coatings: Past, present and future. Trends in Food Sci. \& Tech., 14:71-78.

Vishwasrao, C. and Ananthanarayan, L. 2016. Delayed post-harvest ripeningassociated changes in Manilkara Zapota L. var. Kalipatti with composite edible coting. J Sci Food Agric., 97(2):536542

Youwei and Yinzhe, 2013. Effect of Chitosan Coating on preserving character of Postharvest Fruit and Vegetable, J. Food Proc. and Tech., 4(8): 254-256, doi:10.4172/2157-7110.1000254

\section{How to cite this article:}

Prahlad Deb and Gautam, S. 2018. Ripening Behaviour of Chitosan Coated Sapota Fruits under Low Temperature Storage Condition. Int.J.Curr.Microbiol.App.Sci. 7(10): 2784-2790. doi: https://doi.org/10.20546/ijcmas.2018.710.323 